\title{
ANALISIS HUBUNGAN ANTARA KEKUATAN IKLAN HONDA VERSI ONEHEART TERHADAP KEKUATAN RESPONS KONSUMEN BERDASARKAN METODE CUSTOMER RESPONSE STRENGTH
}

\author{
Trias Aprilianto Nugroho \\ Universitas Muhammadiyah Purwokerto \\ Herni Justiana Astuti \\ Universitas Muhammadiyah Purwokerto
}

\begin{abstract}
This study aims to analyze the correlation the strength of the advertisement Honda One Heart version with the strength of consumer respons student of University Muhammadiyah Purwokerto based by Customer Response Strength (CRS) Methods. Customer Response Strength (CRS) Methods was the one of the measurement methods of the consumer respons to advertisement.The strength of consumer's respons to the advertisement was measured a phase the AIDCA (Attention, Interest, Desire, Conviction an Action) consumer towards the presentation of the advertising. Whereas the strength of the advertisement by a phase of frequency of the consumer saw the advertisement and the consumer's response on the attraction of the advertisement.

The result of the research that indicate a correlation the strength of the advertisement Honda One Heart version with the strength of customer respons at 100 repondents in category strength enough. This is evidenced from value of 0,51 calculated $r$ in interval 0,41 to 0,60 . Whit the result that Honda need to more a considered to for over a frequence in marketing product so that a consumers response toward a brand of Honda gain strength.

Key words: A Strength of Advertisement, A Strength of Consumer Respons, and AIDCA(Attention, Interest, Desire, Conviction and Action)
\end{abstract}

\section{PENDAHULUAN}

\section{A. Latar Belakang Masalah}

Iklan merupakan salah satu strategi berpromosi suatu perusahaan untuk memberikan informasi kepada orang-orang tentang produknya dan mempersuasi pembeli/target pasar saluran distribusi dan publik untuk membeli suatu produk yang ditawarkan oleh perusahaan tersebut. Sedangkan menurut Tjiptono(1997:240), Iklan merupakan bagian dari komunikasi yang terdiri dari berbagai kegiatan untuk memberikan informasi dari komunikasi kepada pasar sasaran akan adanya suatu produk baik berupa barang, jasa dan ide. Berhasil tidaknya iklan yang dilakukan tergantung dari media mana yang digunakan untuk mencapai sasaran.

Pentingnya diadakan riset ini adalah karena media televisi telah menyedot dana terbesar untuk kegiatan promosi (Kotler dan Susanto, 2001). Kelebihan televisi daripada media massa lainya adalah kemampuan menyajikan berbagi kebutuhan manusia baik hiburan, informasi, maupun pendidikan dengan sangat memuaskan. Penonton tidak perlu bersusah payah mencari segala kebutuhan diatas, cukup hanya dengan melhat televisi akan terpenuhi segala kebutuhan tadi dengan cuma-cuma. Data media scene menyebutkan, dari beberapa pilihan pengiklanan sebagai sarana berpromosi, sejak tahun 1994 televisi menyedot sekitar 70\% dari total belanja iklan. Selain itu, Nielsen Media Research mencatat, 
perolehan pertumbuhan iklan televisi pada setiap tahun juga meningkat (Cakram edisi 269, 2006).

Salah satu iklan televisi yang cukup menarik perhatian saat ini adalah iklan Honda versi One Heart, masyarakat mengenal Honda sebagai pabrikan terdepan dalam kemampuan menyuguhkan inovasi dan produk terbaik di pasar yang akhirnya mengantarkannya sebagai pemimpin pasar dalam sejarah industri sepeda motor di tanah air. Dalam kurun waktu hampir 40 tahun Honda telah menjadi mitra bagi hampir 30 juta penggunanya.

Dalam penelitian ini, alasan pemilihan iklan Honda versi One Heart karena iklan tersebut sangat menarik, simpel, mudah dipahami dan musik latar iklan tersebut juga easy listening. Selain itu merek Honda sudah menjadi merek dagang yang betul-betul dicintai dan diterima masyarakat Indonesia. Ini menjadi pertanda Honda merajai pangsa sepeda motor di Indonesia (www. astra-honda.com, 2010).

Iklan yang menarik tentu akan mendapatkan perhatian lebih dari pemirsa. Oleh karena itu kualitas iklan sangat menentukan apakah konsumen akan memberikan respon positif atau respon negatif. Respon positif terjadi ketika konsumen merasa puas, akibatnya probabilitas konsumen untuk melakukan pembelian ulang semakin tinggi.

Perbedaan Penelitian ini dengan penelitian sebelumnya terletak pada produk yang diiklankan yaitu Iklan Pertamina Enduro 4T, sedangkan pada penelitian ini menggunakan iklan Honda versi Oneheart. Perbedaan lainya ada pada obyek penelitian, pada penelilitian terdahulu obyek penelitianya dalah Mahasiswa dan Anggota klub motor di Jogjakarta sedangkan penelitian ini obyek penelitianya yaitu mahasiswa Universitas Muhammadiyah Purwokerto yang keseluruhannya berjumlah 5.650 orang

Penelitian ini bertujuan untuk mengetahui korelasi antara dua variabel yaitu kekuatan iklan Honda versi One Heart dan kekuatan respon audiens terhadap iklan Honda versi One Heart.Pengukuran besarnya kekuatan iklan ini diukur dari tingkat frekuensi audiens dalam melihat iklan Honda versi One Heart dan daya tarik iklan tersebut menurut pandangan audiens.Sedangkan kekuatan respon diukur melalui metode CRS (Customer Respons Strength).Pengukuran besarnya kekuatan respon ini dilihat dari sampai pada tahapan AIDCA (Attention-Interest-Desire-Conviction-Action) yang manakah audiens tersebut. Pemilihan metode CRS (Customer Respons Strength) didasarkan pada fakta bahwa metode ini adalah salah satu cara untuk mengukur kekuatan respon konsumen yang dipengaruhi oleh kekuatan iklan. Berdasarkan konsep AIDCA, promosi periklanan harus diperlukan pengetahuan yang cukup tentang pola perilaku, kebutuhan, dan segmen pasar.Konsep tersebut diharapkan konsumen dapat melakukan pembelian berkesinambungan.

\section{B. Kerangka Pemikiran}

Setiap pelaku bisnis dalam memasarkan produknya pada konsumen dilakukan dengan cara memberikan rangsangan (stimulus) dari luar berupa promosi dan iklan. Rangsangan ini menghasilkan jawaban dari pembeli sehingga akan memunculkan respon (reaksi) untuk memilih produk yang dibelinya. Seperti yang dikemukakan oleh Simamora ( 2003,p. 126) bahwa, "respon adalah reaksi konsumen terhadap suatu stimuli tertentu ". Dan menurut Swastha dan Handoko (1997,p. 91), "Respon adalah prediposisi (keadaan mudah dipengaruhi) untuk memberikan pendapat terhadap lingkungan, yang dapat memulai atau membimbing tingkah laku orang tersebut". Dari kedua definisi diatas menunjukan bahwa respon itu timbul bila ada stimuli yang kemudian ditanggapi sehingga timbul keinginan untuk bertindak. Respon hanya akan ada bila digambarkan dalam bentuk perilaku lisan dan dalam perilaku perbuatan, lalu timbul suatu proses evaluasi yang menentukan apakah menerima atau menolak terhadap obyek atau produk 
yang dihadapi. ). Pengukuran besarnya kekuatan respon ini dilihat dari sampai pada tahapan AIDCA (Attention-Interest-Desire-Conviction-Action) yang manakah audiens tersebut. Pemilihan metode CRS (Customer Respons Strength) didasarkan pada fakta bahwa metode ini adalah salah satu cara untuk mengukur kekuatan respons konsumen yang dipengaruhi oleh kekuatan iklan. Berdasarkan konsep AIDCA

Iklan yang menarik tentu akan mendapatkan perhatian lebih dari pemirsa. Oleh karena itu kualitas iklan sangat menentukan apakah konsumen akan memberikan respon positif atau respon negatif. Respon positif terjadi ketika konsumen merasa puas, akibatnya probabilitas konsumen untuk melakukan pembelian ulang semakin tinggi.Kekuatan positif adalah hal-hal yang diterima konsumen karena mengkonsumsi atau membeli suatu produk (Sumarwan, 2003: 110). Pengaruh tersebut adalah meningkatkan kecendrungan seorang konsumen untuk membeli ulang produk tersebut. Produk yang mempunyai kekuatan adalah produk yang dibeli dan dikonsumsi oleh konsumen, produk tersebut dengan sendirinya akan memberikan penguatan kepada konsumen apakah akan membeli ulang produk tersebut atau menghentikannya (Sumarwan, 2003:112). Berdasarkan kerangka pemikiran di atas maka dapat dibuat kerangka pemikiran berikut ini:

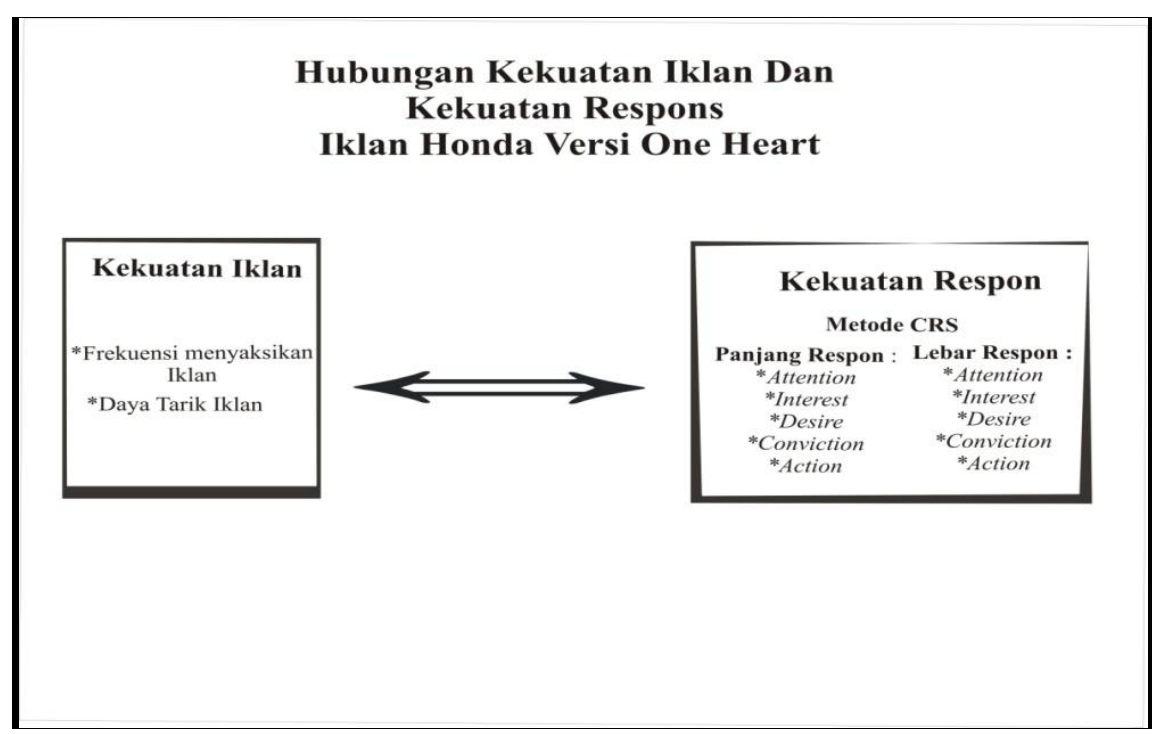

Gambar 2.1

\section{Hipotesis}

1. Diduga besarnya rata-rata (average) kekuatan iklan Honda versi One Heart berada pada kategori kuat.

2. Diduga besarnya rata-rata (average) kekuatan respon konsumen di lihat dari metode CRS (Customer Respons Strength) berada pada kategori kuat.

3. Diduga adanya hubungan yang kuat antara kekuatan iklan Honda versi "One Heart" dan kekuatan respon konsumen.

\section{METODE PENELITIAN}

\section{A. Jenis Penelitian}

Penelitian ini menggunakan desain riset kausalitas. Riset Kausalitas menurut Churchill yaitu riset yang bertujuan untuk menentukan hubungan dari suatu sebab akibat atau 
hubungan mempengaruhi dan dipengaruhi oleh variabel-variabel yang diteliti, maka desain riset inilah yang digunakan untuk menjelaskan Hubungan antara kekuatan iklan Honda versi One Heart terhadap kekuatan respon konsumen. (Churchill, 2005)

\section{B. Obyek Penelitian}

Obyek penelitian Hubungan antara kekuatan Honda versi One Heart terhadap kekuatan respons konsumen adalah mahasiswa Universitas Muhammadiyah Purwokerto baik pria maupun wanita yang pernah memakai, mempunyai, atau pernah menggunakan produk sepeda motor Honda dan pernah melihat iklan televisi Honda versi One Heart.

\section{Metode Pengambilan Sample}

Metode sampling yang digunakan penulis dalam penelitian ini adalah Purposive sampling. yaitu pengambilan sampel yang didasarkan pada pertimbangan untuk menyesuaikan dengan kriteria penelitian agar dapat meningkatkan ketepatan sampel (Arikunto, 2002).

Kriteria yang digunakan adalah :

1. Responden yang mempunyai, memakai atau pernah menggunakan kendaraan sepeda motor Honda saat penelitian dilakukan.

2. Responden tahu atau pernah melihat iklan Honda versi One Heart.

3. Responden merupakan Mahasiswa Universitas Muhammadiyah Purwokerto. Sedangkan cara untuk memperoleh data yaitu dengan:

1) Wawancara adalah metode pengumpulan data dengan cara melakukan tanya jawab kepada pihak-pihak yang memiliki relevansi dengan penelitian ini

2) Kuesioner yaitu mengumpulkan data dan informasi dengan membagikan daftar pertanyaan yang disusun secara sistematis kepada responden berkaitan dengan masalah yang diteliti.

3) Pengamatan langsung adalah metode pengumpulan data melalui pengamatan, pencatatan dan analisa secara langsung terhadap gejala-gejala (fenomena) yang terjadi secara sistematis pada objek penelitian.

4) Studi pustaka yaitu mengumpulkan data dan informasi yang bersifat teoritikal dengan cara menelaah berbagai literatur, jurnal penelitian, majalah serta sumber pustaka lainya yang berkaitan dengan penelitian.

Populasi adalah jumlah keseluruhan dari subyek-subyek yang karakteristiknya akan diduga. Populasi dalam penelitian ini adalah mahasiswa Universitas Muhammadiyah Purwokerto. Sedangkan metode pengambilan sampel yang digunakan dalam penelitian ini adalah metode purposive sampling yaitu teknik penentuan sampel dengan pertimbangan tertentu (Sugiyono, 2007). Adapun kriteria pengambilan sampel dalam penelitian ini adalah mahasiswa Universitas Muhammadiyah Purwokerto. Adapun jumlah mahasiswa Universitas Muhammadiyah Purwokerto sebanyak 5.650 orang. Untuk mendapatkan sampel yang menggambarkan dan mewakili populasi, maka penentuan sampel dalam penelitian ini digunakan rumus Slovin (Umar, 2002) sebagai berikut:

$n=\frac{N}{1+N e^{2}}$

Keterangan :

$N$ : Jumlah populasi 
$n$ : Jumlah sampel

e : Prosentase tingkat kesalahan yang ditoleransi adalah 5\%

Dengan jumlah populasi sebanyak 5.650 responden, jika tingkat kesalahan pengambilan sampel sebesar $10 \%$, maka sampel minimum dapat dihitung sebagai berikut :

$$
\mathrm{n}=\frac{5650}{1+5650(0,1)^{2}}=98,26
$$

Jadi jumlah sampel minimum yang digunakan sebagai responden dalam penelitian ini adalah sebanyak 98 (pembulatan) orang/ konsumen pada mahasiswa Universitas Muhammadiyah Purwokerto, namun untuk mengantisipasi tidak kembali dan rusaknya kuesioner, peneliti akan menyebar kuesioner sebanyak 110 yang dibagikan ke 10 fakultas yang ada di Universitas Muhammadiyah Purwokerto.

\section{HASIL PENELITIAN DAN PEMBAHASAN}

\section{A. Respon Rate}

Dalam penelitian ini kuesioner dibagikan kepada mahasiswa Universitas Muhammadiyah Purwokerto dengan metode purposive sampling yaitu teknik penentuan sampel dengan pertimbangan tertentu (Sugiyono, 2007). Kuesioner yang dibagikan sebanyak 110. Dari jumlah tersebut kuesioner yang dikembalikan oleh responden sebanyak 103, kuesioner yang kembali tidak lengkap 3 dan terdapat 7 kuesioner yang tidak kembali. Dengan demikian terdapat 100 yang dapat dianalisis.

\section{B. Uji Validitas Kuesioner}

Pengujian validitas kuesioner dalam penelitian ini menggunakan rumus korelasi product moment. Analisis validitas kuesioner meliputi variabel kekuatan iklan dan kekuatan respon. Adapun ringkasan hasil uji validitas kuesioner dapat dilihat pada Tabel 4.3

Tabel 4.3 Uji Validitas Kuesioner Variabel Kekuatan Iklan

\begin{tabular}{|c|c|c|c|}
\hline Item & $r_{\text {hitung }}$ & $\begin{array}{c}r_{\text {tabel }} \\
\text { (Taraf Kepercayaan } 95 \%)\end{array}$ & Keterangan \\
\hline 1 & 0,932 & 0,198 & Valid \\
\hline 2 & 0,836 & 0,198 & Valid \\
\hline
\end{tabular}

Berdasarkan Tabel 5 dapat diketahui bahwa nilai $r$ hitung korelasi product moment semua item pertanyaan untuk variabel kekuatan iklan lebih besar dari nilai kritis ( $r$ tabel) sebesar 0,198 pada tingkat kepercayaan $95 \%$, dengan demikian maka seluruh item pertanyaan untuk variabel kekuatan iklan dinyatakan valid dan dapat digunakan sebagai alat pengumpulan data.

Tabel 4.3 Pengujian Validitas Kuesioner Variabel Kekuatan Respon

\begin{tabular}{llll}
\hline Item & $r_{\text {hitung }}$ & $\begin{array}{l}r_{\text {tabel }} \\
(\text { Taraf Kepercayaan 95\%) }\end{array}$ & Keterangan \\
\hline 1 & 0,599 & 0,198 & Valid \\
2 & 0,656 & 0,198 & Valid \\
3 & 0,773 & 0,198 & Valid \\
4 & 0,762 & 0,198 & Valid \\
5 & 0,725 & 0,198 & Valid \\
\hline
\end{tabular}

Berdasarkan Tabel 4.3 dapat diketahui bahwa nilai $r_{\text {hitung korelasi product moment }}$ semua item pertanyaan untuk variabel kekuatan respon lebih besar dari nilai kritis ( $r$ tabel) 
sebesar 0,198 pada tingkat kepercayaan $95 \%$. Dengan demikian, maka seluruh item pertanyaan untuk variabel kekuatan respon dinyatakan valid dan dapat digunakan sebagai alat pengumpulan data.

\section{Uji Reliabilitas Kuesioner}

Pengujian reliabilitas item pertanyaan/pernyataan kuesioner dalam penelitian ini menggunakan rumus spearman brown (ganjil-genap). Suatu kuesioner penelitian dinyatakan reliabel jika nilai $r_{\text {hitung }}$ lebih besar dari nilai $r_{\text {tabel. }}$

Tabel 4.4. Pengujian Reliabilitas Kuesioner

\begin{tabular}{llll}
\hline Variabel & $\begin{array}{l}\text { Koefisien } \\
\text { Reliabilitas }\end{array}$ & $\mathrm{r}_{\text {tabel }}$ & $\begin{array}{l}\text { Keteranga } \\
n\end{array}$ \\
\hline Kekuatan iklan & 0,7341 & 0,198 & Reliabel \\
Kekuatan respon & 0,7421 & 0,198 & Reliabel \\
\hline
\end{tabular}

Berdasarkan Tabel 4.4 dapat diketahui bahwa koefisien reliabilitas untuk variabel kekuatan iklan maupun kekuatan respon masing-masing lebih besar dari kritis ( $r$ tabel) sebesar 0,198 , sehingga semua item pertanyaan/pernyataan untuk setiap variabel tersebut dinyatakan reliabel dan dapat digunakan sebagai alat pengumpulan data.

D. Uji Analisis Data

Diketahui indeks respon para mahasiswa Universitas Muhammadiyah Purwokerto terhadap iklan Honda versi One Heart yang dapat dilihat pada

Indeks Respon Responden pada Iklan Honda Versi One Heart

\begin{tabular}{|c|c|c|c|}
\hline $\begin{array}{c}\text { Tahap } \\
\text { Maksimal } \\
\text { Yang } \\
\text { Dilalui }\end{array}$ & $\begin{array}{c}\text { Kekuatan } \\
\text { Respon }\end{array}$ & Frekuensi & Total \\
\hline \multirow{4}{*}{ Attention } & NAT & 0 & 0 \\
\hline & AT1 & 71 & \multirow{3}{*}{100} \\
\hline & AT2 & 26 & \\
\hline & AT3 & 3 & \\
\hline \multirow{4}{*}{ Interest } & $\mathrm{NI}$ & 1 & 1 \\
\hline & 11 & 71 & \multirow{3}{*}{99} \\
\hline & 12 & 22 & \\
\hline & 13 & 6 & \\
\hline \multirow{6}{*}{ Desire } & ND & 2 & 2 \\
\hline & D1 & 23 & \multirow{3}{*}{98} \\
\hline & $\mathrm{D} 2$ & 66 & \\
\hline & D3 & 9 & \\
\hline & $\mathrm{NC}$ & 2 & 2 \\
\hline & C1 & 8 & \\
\hline
\end{tabular}




\begin{tabular}{|c|c|c|c|}
\hline Conviction & C2 & 83 & \multirow{2}{*}{98} \\
\cline { 2 - 3 } & C3 & 7 & \\
\hline \multirow{3}{*}{ Action } & NAC & 2 & 2 \\
\cline { 2 - 3 } & AC1 & 24 & \multirow{2}{*}{98} \\
\cline { 2 - 3 } & AC2 & 49 & \\
\cline { 2 - 3 } & AC3 & 25 & \\
\hline
\end{tabular}

Berdasarkan Tabel 4.12 dapat diketahui bahwa keseluruhan responden (100\%) menaruh perhatian (attention) terhadap iklan Honda versi One Heart.

Tabel 4.13 Pengujian Reliabilitas Kuesioner

\begin{tabular}{llll}
\hline No & $\begin{array}{l}\text { Tahap Maksimal Yang } \\
\text { Dilalui }\end{array}$ & Frekuensi & $\begin{array}{l}\text { Persentase } \\
\text { Total }\end{array}$ \\
\hline 1 & Attention & 100 & $100,00 \%$ \\
2 & Interest & 99 & $99,00 \%$ \\
3 & Desire & 98 & $98,00 \%$ \\
4 & Conviction & 98 & $98,00 \%$ \\
5 & Action & 98 & $98,00 \%$ \\
\hline
\end{tabular}

Berdasarkan Tabel 4.13 dapat diketahui bahwa 98 orang atau $98 \%$ dari keseluruhan jumlah responden melalui tahap maksimal sampai dengan action dari persepsi mereka terhadap iklan Honda versi One Heart.

\section{E. Pengujian Hipotesis}

\section{Pengujian Hipotesis Pertama}

Hipotesis Pertama diterima jika Nilai Rata - Rata kekuatan iklan Honda versi One Heart 1,61 sampai dengan 4,80.

Untuk mengetahui kekuatan iklan Honda versi One Heart dilakukan perhitungan nilai rata-rata persepsi responden terhadap kekuatan iklan, yang dapat dilihat seperti tertera pada Tabel 4.14

Tabel 4.14. Nilai Rata-rata Kekuatan Iklan Honda Versi One Heart

\begin{tabular}{llll} 
Sum & 242 & 79 & 232 \\
\hline Mean 2.42 & 0.79 & 2.32 \\
\hline
\end{tabular}

Berdasarkan Tabel 4.14 dapat diketahui bahwa nilai rata-rata frekuensi menyaksikan iklan Honda versi One Heart sebesar 2,42, nilai rata-rata daya tarik iklan Honda versi One Heart sebesar 0,79, sehingga nilai rata-rata kekuatan iklan Honda versi One Heart sebesar 2,32. Nilai rata-rata kekuatan iklan tersebut berada pada interval nilai antara 1,61 sampai dengan 4,80. Dengan demikian, maka hipotesis pertama yang menyatakan bahwa diduga besarnya rata-rata (average) kekuatan iklan Honda versi One Heart berada pada kategori kuat, diterima.

\section{Pengujian Hipotesis Kedua}

Hipotesis kedua diterima jika Nilai Rata - Rata kekuatan respon berada diantara 27,01 sampai dengan 36,00 . 
Pengujian hipotesis kedua dalam penelitian ini yaitu mengetahui dan menganalisis kekuatan respon terhadap iklan Honda versi One Heart berdasarkan metode Customer Respons Strength dilakukan dengan mencari nilai rata-rata persepsi responden terhadap kekuatan respon, yaitu dengan rumus CRS (Score Attention $\times 1)+($ Score Interest $\times 2)+$ $($ Score Desire $\times 3)+($ Score Conviction $\times 4)+($ Score Action $\times 5)$

yang dapat dilihat pada Tabel 4.15

Tabel 4.15 Rata-rata Customer Respons Strength Iklan Honda Versi One Heart

\begin{tabular}{lllllll}
\hline Sum & 132 & 266 & 546 & 780 & 985 & 2.709 \\
\hline Mean & 1,32 & 2,66 & 5,46 & 7,80 & 9,85 & 27,09 \\
\hline
\end{tabular}

Berdasarkan Tabel 4.15 dapat diketahui bahwa nilai rata-rata attention responden pada iklan Honda versi One Heart sebesar 1,32, nilai rata-rata interest responden pada iklan Honda versi One Heart sebesar 2,66, rata-rata desire responden pada iklan Honda versi One Heart sebesar 5,46, rata-rata conviction responden pada iklan Honda versi One Heart sebesar 7,80 dan rata-rata action responden pada iklan Honda versi One Heart sebesar 9,85 sehingga nilai rata-rata kekuatan respon pada iklan Honda versi One Heart sebesar 27,09 . Nilai rata-rata kekuatan respon tersebut berada pada interval nilai antara 27,01 sampai dengan 36,00 . Dengan demikian, maka hipotesis kedua yang menyatakan bahwa diduga besarnya rata-rata (average) kekuatan respon konsumen terhadap iklan Honda versi One Heart berdasarkan metode Customer Respons Strength berada pada kategori kuat, diterima

\section{Pengujian Hipotesis Ketiga}

Hipotesis ketiga diterima jika Nilai Korelasi antara kekuatan iklan dan kekuatan respon berada diantara 0,61 sampai dengan 0,80 .

Pengujian hubungan atau korelasi antara kekuatan iklan dengan kekuatan respon pada iklan Honda versi One Heart dalam penelitian ini menggunakan uji korelasi rank spearman, dengan hasil sebagai berikut :

Tabel 4.16 Output Korelasi Rank Spearman

\begin{tabular}{|c|c|c|c|c|}
\hline \multicolumn{5}{|c|}{ Correlations } \\
\hline & & & $\begin{array}{c}\text { Kekuatan } \\
\text { Iklan }\end{array}$ & $\begin{array}{l}\text { Kekuatan } \\
\text { Respon }\end{array}$ \\
\hline \multirow[t]{2}{*}{ Spearman's rho } & Kekuatan Iklan & $\begin{array}{l}\text { Correlation Coef ficient } \\
\text { Sig. (2-tailed) } \\
\mathrm{N}\end{array}$ & $\begin{array}{r}1,000 \\
, \\
100\end{array}$ & $\begin{array}{r}, 510^{\star} \\
, 000 \\
100\end{array}$ \\
\hline & Kekuatan Respon & $\begin{array}{l}\text { Correlation Coef ficient } \\
\text { Sig. (2-tailed) } \\
\mathrm{N}\end{array}$ & $\begin{array}{c}, 510^{* *} \\
, 000 \\
100\end{array}$ & $\begin{array}{r}1,000 \\
, \\
100\end{array}$ \\
\hline
\end{tabular}

${ }^{* *}$. Correlation is signif icant at the .01 level (2-tailed).

Output korelasi dengan bantuan software SPSS 17.0 for Windows pada Tabel 4.16 menunjukkan bahwa nilai $r$ hitung korelasi rank spearman sebesar 0,510 dengan nilai signifikansi 0,000 lebih kecil dari $\alpha(0,05)$. Nilai $r$ hitung tersebut berada pada interval nilai antara 0,41 sampai dengan 0,60. Hal tersebut menunjukkan bahwa terdapat hubungan positif yang cukup kuat antara kekuatan iklan dengan kekuatan respon. Dengan demikian, maka hipotesis ketiga yang menyatakan bahwa diduga adanya hubungan yang kuat antara kekuatan iklan dengan kekuatan respon pada iklan Honda versi "One Heart", ditolak. 


\section{F. Pembahasan}

Pengujian hipotesis pertama dalam penelitian ini membuktikan bahwa besarnya ratarata (average) kekuatan iklan Honda versi One Heart berada pada kategori kuat. Hal ini menunjukkan bahwa secara umum mahasiswa Universitas Muhammadiyah Purwokerto selaku responden dalam penelitian ini tertarik dan menyukai iklan Honda versi One Heart. Hal tersebut ditunjukkan dengan tingginya frekuensi menonton dan memperhatikan iklan tersebut serta memberikan penilaian yang baik mengenai daya tarik iklan tersebut, sehingga image Honda sebagai salah satu merek produk sepeda motor semakin kuat di benak konsumen atau masyarakat secara luas. Hal ini sesuai dengan teori dari Kotler (2004) yang menyatakan bahwa periklanan menjalankan fungsi "pengingat", dimana iklan pengingat sangat penting bagi produk yang sudah mapan. Bentuk iklan yang berhubungan dengan iklan ini adalah iklan penguat (inforcement advertising) yang bertujuan meyakinkan pembeli sekarang bahwa mereka telah melakukan pilihan yang benar.

Pengujian hipotesis kedua dalam penelitian ini membuktikan bahwa besarnya ratarata (average) kekuatan respon konsumen terhadap iklan Honda versi One Heart berdasarkan metode Customer Respons Strength berada pada kategori kuat. Hasil pengujian ini menunjukkan bahwa secara umum mahasiswa Universitas Muhammadiyah Purwokerto selaku responden dalam penelitian ini memberikan respon yang baik terhadap iklan Honda versi One Heart. Respon baik tersebut ditunjukkan melalui tingginya tingkat perhatian (attention) responden terhadap iklan Honda versi One Heart yang kemudian menumbuhkan minat (interest) dari sebagian besar responden terhadap sepeda motor merek Honda, dimana minat yang kuat selanjutnya menumbuhkan harapan (desire) terhadap karakteristik produk merek Honda. Karakteristik produk yang berkualitas selanjutnya akan mendorong rasa percaya (conviction) dari sebagian besar responden terhadap produk merek Honda dan hal tersebut selanjutnya diwujudkan melalui tindakan (action), baik dalam bentuk minat beli konsumen maupun keputusan pembelian produk merek Honda. Assael (2001) menyatakan bahwa iklan yang di tayangkan media televisi membentuk pernyataan sikap konsumen yang mempengaruhi minat beli konsumen. Pembentukan sikap terhadap iklan dipengaruhi oleh persepsi konsumen terhadap iklan. Sikap terhadap iklan ini diawali cara konsumen berfikir mengenai sebuah iklan.

Pengujian hipotesis ketiga dalam penelitian ini menunjukan bahwa antara variabel kekuatan iklan dan variabel kekuatan respon iklan Honda versi "One Heart terdapat adanya hubungan positif yang cukup kuat. Hasil dari pengujian hipotesis ketiga menunjukkan bahwa hubungan antara variabel kekuatan iklan dan variabel kekuatan respon iklan Honda versi "One Heart berada dalam kategori cukup kuat. Hasil tersebut ditunjukan oleh perubahan persepsi responden (baik kenaikan maupun penurunan) berkaitan dengan frekuensi menonton dan daya tarik dari iklan Honda versi "One Heart dan diikuti dengan perubahan (baik kenaikan maupun penurunan) respon dari sebagian besar responden berkaitan dengan perhatian (attention), minat (interest), harapan (desire), rasa percaya (conviction) dan tindakan (action) terhadap produk merek Honda, meskipun perubahan yang terjadi berkaitan dengan kekuatan iklan tidak sebanding dengan perubahan yang terjadi berkaitan dengan kekuatan respon dari sebagian besar responden. Hasil penelitian ini dapat dipertanggungjawabkan secara ilmiah, karena Assael (2001) menyatakan bahwa sikap terhadap iklan merupakan kecenderungan konsumen untuk menjawab dengan baik atau tidak baik terhadap iklan tertentu. Di samping itu, untuk mencapai keberhasilan iklan dalam merangsang tindakan pembelian oleh konsumen melalui proses perhatian (attention), minat (interest), harapan (desire), rasa percaya (conviction) dan tindakan (action) dipengaruhi oleh 
banyak faktor di luar kekuatan iklan tersebut. Kotler (2004) menyebutkan bahwa faktorfaktor yang dapat merangsang tindakan pembelian oleh konsumen diantaranya adalah kekuatan merek, karakteristik konsumen, rangsangan perusahaan yang mencakup produk, harga, tempat dan promosi. Oleh karena itu, hasil penelitian ini yang membuktikan adanya hubungan positif yang cukup kuat antara kekuatan iklan dengan kekuatan respon pada iklan Honda versi "One Heart sangat beralasan mengingat bahwa kekuatan iklan hanyalah salah satu faktor penentu yang berhubungan dengan kekuatan respon.

\section{KESIMPULAN DAN SARAN}

\section{A. Kesimpulan}

1. Rata-rata (average) kekuatan iklan Honda versi One Heart berada pada kategori kuat. Hal tersebut dibuktikan melalui hasil perhitungan, dimana diperoleh nilai rata-rata kekuatan iklan berada pada interval nilai antara 1,61 sampai dengan 4,80.

2. Rata-rata (average) kekuatan respon konsumen terhadap iklan Honda versi One Heart berdasarkan metode Customer Respons Strength berada pada kategori kuat. Hal tersebut dibuktikan melalui hasil perhitungan, dimana diperoleh nilai rata-rata kekuatan respon berada pada interval nilai antara 27,01 sampai dengan 36,00.

3. Terdapat hubungan positif yang cukup kuat antara kekuatan iklan dengan kekuatan respon pada iklan Honda versi "One Heart. Hal tersebut dibuktikan melalui hasil analisis korelasi rank spearman, dimana diperoleh nilai $r$ hitung berada pada interval nilai antara 0,41 sampai dengan 0,60 .

\section{B. Saran}

1. Rata-rata kekuatan iklan Honda versi One Heart berada pada kategori kuat, maka pihak pemasar sepeda motor merek Honda perlu mempertahankan image dan secara terusmenerus memperkuat image merek Honda melalui pemberian informasi secara jelas dan obyektif serta proporsional kepada masyarakat sebagai konsumen berkaitan dengan atribut-atribut produk Honda.

2. Sebagai upaya dalam mempertahankan eksistensi dan meningkatkan kemampuan Honda dalam memenangkan persaingan bisnis otomotif, pihak pemasar sepeda motor merek Honda perlu menjaga respon konsumen terhadap iklan yang ditayangkan, dengan cara terus meningkatkan dan mengoptimalkan potensi atribut yang dimiliki produk Honda, terutama atribut yang masih belum dikembangkan secara optimal sesuai dengan kebutuhan dan keinginan atau harapan konsumen.

3. Adanya hubungan positif yang cukup kuat antara kekuatan iklan dengan kekuatan respon pada iklan Honda versi "One Heart, maka pihak pemasar sepeda motor merek Honda perlu meningkatkan frekuensi dalam memasarkan produk Honda, agar respon konsumen terhadap merek Honda semakin kuat.

\section{DAFTAR PUSTAKA}

Arikunto, 2002, Prosedur Suatu Pendekatan Dan Praktek. Jakarta : PT. Rineka Cipta.

Assael, Henry. 2001.Consumer Behavior, and Marketing Action Fifth Edition. 2001. Thomson Learning 
Bayu Swastha dan Hani Handoko, Manajemen Pemasaran Analisis Perilaku Konsumen. BPFE, Yogyakarta, 1997

Caples, Jhon. Tested Advertising Method. Fifth Edition. Prentice Hall, 1997.

Churchill, Gilbert A. 2005. "Dasar Dasar Riset Pemasaran”, Edisi 4, Jilid 1, Alih Bahasa Oleh Andriani, Dkk, Penerbit Erlangga, Jakarta.

Darmadi Durianto,Sugiarto,Anton.W.Widajaj,Hendrawan.S. Invasi Pasar Dengan Iklan Yang Efektif, PT.Gramedia Pustaka Utama Jakarta, 2003

Khasali Rheinald, 1992. Manajemen Pemasaran, Konsep dan Aplikasinya di Indonesia. PT Grafiti, Jakarta

Kotler, Philip. 2000. Manajemen Pemasaran. Jilid 1. Jakarta: PT Prenhalindo .2002. Manajemen Pemasaran. Edisi Kesebelas. Jakarta: PT Prenhalindo.

Kotler Philip, Swee Hoon Ang, Siew Meng Leong, Chin Ting Tan. 2004. Manajemen Pemasaran Sudut Pandang Asia. Edisi Ketiga. Indonesia: Indeks.

A.B. Susanto. 2001. Manajemen Pemasaran di Indonesia. Salemba Empat, Jakarta. . 2001. Manajemen Pemasaran. Jilid 2. Jakarta : Prenhallindo.

. 2000. Manajemen Pemasaran Indonesia. Edisi Millenium. Jakarta: PT Ikrar Mandiri Abadi

Royan, Frans M, 2004, "Marketing Celebbrities", PT Elex Media Komputindo Kelompok Gramedia, Jakarta.

Ruslam. Y.2006. Kenaikan Belanja Iklan Televisi Di Indonesia. Cakram edisi 269, 2006, Jakarta

Sitanggang, P,. 2007. Analisis Hubungan Antara Kekuatan Iklan Pertamina Enduro 4T Terhadap Kekuatan Respons Konsumen Berdasarkan Metode CRS. http://puslit.petra.ac.id/journals/marketing.

Simamora, B. 2001. Remarketing For Business Recovery. Jakarta: PT Gramedia. . 2003. Membongkar Kotak Hitam Konsumen. Jakarta: PT Gramedia. 2004. Panduan Riset Perilaku Konsumen. Jakarta: PT Gramedia.

Sugiyono. 2004. Metode Penelitian Administrasi. Alfabeta. Jakarta

Sumarwan, Ujang.2003.Perilaku Konsumen. Jakarta: PT. Ghalia Indonesia.

Supranto. J. 1993. Metode Riset : Aplikasi dalam Pemasaran. Jakarta: Lembaga Penerbit FE Universitas Indonesia. 
Tjiptono, F.1997. Strategi Pemasaran, Cetakan Pertama, Yogyakarta: Andi Offset. 2001. Strategi Pemasaran. Yogyakarta: Andi Offset.

Umar, Husen. 2000. Riset Pemasaran dan Perilaku Konsumen. PT Gramedia Pustaka Utama.

\section{INTERNET:}

PT Astra Honda Motor, 2010. Honda Meluncurkan tagline Baru One Heart. www.astra-honda.com. 11 Oktober 2010.

Edwi. A. 2006. Media Iklan. http://www.edwias.com,2006/media iklan. 16 Mei 2010 